\title{
Integrated Farming System Model in South Minahasa Regency- North Sulawesi
}

\author{
Meiske Lusye Rundengan ${ }^{1,3}$, Zaenal Fanani ${ }^{2}$, Ifar Subagiyo ${ }^{2}$, Femi Hadidjah Elly $^{3}$ \\ ${ }^{I}$ A Doctoral Program Student, Faculty of Animal Husbandry, Brawijaya University \\ ${ }^{2}$ A lectuer at Faculty of Animal Husbandry, Brawijaya University \\ ${ }^{3}$ A lectuer at Faculty of Animal Husbandry, Sam Satulangi University
}

\begin{abstract}
Indonesia's animal protein needs keep increasing. The rate of population increase followed by improvement of standard of living and changes of consumer'staste has changed consumption patterns toward animal protein from livestock.Integrated Farming System (Sistem integrasi tanaman-ternak or SITT), whether plantation crops or feed crops, is a potential alternative which can solve the problem of plantation business, feed crops and even livestock problems. The aim of this study is to investigate integrated farming system in North Sulawesi. Data analysis tool used was Analysis of Variance (ANOVA) and linear regression analysis. ANOVA was used to compare income and cost of agricultural business on various types of business. Regression analysis was used to test factors influencing the income of integrated farming system. The result of this study show that integrated farming system which involves food crops in coconuts and cows systems produced higher income than coconuts-cows system, or non-integrated coconut and cows. The recommendation from the study is to optimize coconut farms with food crops and livestock to increase farmers' income. Thus, there should be further study to improve techniques of cultivating food crops between coconut trees, so that coconut and food crops production will increase.
\end{abstract}

Keywords:Integrated Farming System, South Minahasa, Coconut, Cow

\section{Introduction}

Indonesia's animal protein needs keep increasing. The rate of population increase followed by improvement of standard of living and changes of consumer'staste has changed consumption patterns toward animal protein from livestock. Meats, eggs and milk are high protein good commodities, which are generally more expensive than other foodstuffs (Priyanto, 2011). According to Diwyanto and Handiwirawan (2005), in the next decade there will be changes of society's consumption patterns, i.e. demands for livestock products along with vegetable oil and horticultures will increase quite sharply. The increase of meat consumption hadn't been matched by increase of national production, whether in quality or quantity, so that there is a growing gap between demand and supply (Saisoong, 1987).

The population of beef cattle in North Sulawesi Province is still low. According to Ifar (2007), compared with other provinces in Sulawesi, beef cattle population in North Sulawesi is the lowest. In 2005, beef cattle population in North Sulawesi Utara was just $7.3 \%$ of total cow population in Sulawesi $(1,369,585)$. If negative cow population increase above continues, coupled with the small population compared with other provinces in Sulawesi, then the contribution of North Sulawesi Province to meeting national meat needs will be more marginal. Therefore, there should be efforts to increase cow population in North Sulawesi by utilizing available resources optimally.

North Sulawesi has great potential for the development of cattle businesses. This is because North Sulawesi has natural resources (fodder), human resources and adequate market opportunity which haven't utilized optimally. According to Paat (2009a), the development North Sulawesi as a corn-producing area makes corn waste available in abundance, and large coconut plantation areas can be used for herding areas. Corn waste can be used as animal feed to reduce feed cost. Haryanto (2009) adds that in crop regions, especially paddy, there is great potential as the source of fibrous feed for ruminants in rice straws. This, the issue of lack of feed throughout the year, especially if only depending on seasons, can be solved by intensification of agricultural waste utilization. Adequate fodder availability potential of plants waste throughout the year will reduce dependency to fodders from outside the region and guarantee the continuation of cattle businesses (Eli et al., 2008). Through optimal natural resources management, North Sulawesi Province has great opportunity to become beef cattle-producing area.

Integrated Farming System (Sistem integrasi tanaman-ternak or SITT), whether plantation crops or feed crops, is a potential alternative which can solve the problem of plantation business, feed crops and even livestock problems. According to Haryanto (2009), Integrated faming system integrates all components of agriculture business horizontally and vertically, so that no waste is wasted. The system is very environmentally friendly and able to expand income sources and reduce failure risks. Feed crops waste shows great potential in 
solving feeding problems at farmer's level. Manure which is livestock waste can be utilized as soil organic material source. Compost is organic fertilizer source for plants, as well as for soil amendment. The utilization agriculture waste so that nothing is wasted can conserve the nutrients cycle from soil-plants-livestock-back to soil perfectly. This environmental wisdom should be cultivated widely to preserve natural resources.

In North Sulawesi, cows are tended along with plants, known as integrated farming system. Integrated system is an implementation of integrated agriculture using low external inputapproach between cattle and plants. The result of PRA in North Sulawesi BPTP (2003 in Melia et al., 2010) showed that many farmers in North Sulawesi cultivate coconuts using polyculture or integrate certain livestock such as cows, goats, etc., but it's not properly organized, causing low agricultural efficiency. Coconut farms in coastal areas to the height of $100 \mathrm{~m}$ asl often use intercrops, especially corn and secondary food crops, as well as for cattle herding areas, especially cows. Based on the background and thought above, the aim of this study is to investigate integrated farming system in North Sulawesi

\section{Previous Research}

\section{Materials and Methods}

Traditional farming technology is an art passed down verbally as well as through demonstrations from one farmer generation to next based on years of local observation and experiences. Cattle business is a process combining production factors such as land, livestock, labors, and capitals to produce livestock products. Smallholder farmers beef cattle businesses are usually breeding (calf production) or calves growing with low external input. Business management is performed traditionally by using local resources (labor intensive), not oriented on profit because it counts on familial labors, and ran in a small scale (Priyanto, 2011). The production objectives of smallholders farms are to produce calves, for agricultural labors and to have cash when in needs (Santoso, 2003).

Farms in Indonesia are still dominated by traditional farmers. Based on the actors, cattle business in Indonesia generally can be grouped into three categories, i.e. 1) managed by farmers traditionally, 2) managed commercially by major companies, and 3) managed by core-plasma system. Generally, livestock production in Indonesia is dominated by small scale cattle businesses managed traditionally $(99,70 \%)$ and the remaining $0,30 \%$ is managed by large scale companies (Eli et al., 2008). According to Moog (2006), most traditional farmers keep 1 or 2 cows for agricultural transportation and will send the cattle when they need cash. While according to Suryana (2008), traditional farmers' human resources skills are still low. Some of the weaknesses of the human resources are weak mastery of market information access (input-output), production inputs owned are usually only lands and labors, low education so that adoption of new technologies is slow, disorganized so the actions are ineffective and inefficient, weak bargaining position, low level of needs, generally prioritizing primary needs, avoiding risks of failures, unwillingness of invest, personal relationship patterns and having many interests.

Farms in North Sulawesi are dominated by small-scale smallholders farms which are run on the side. In developing the businesses, generally farmers lack the capital (Eli et al., 2008). According to Diwyantoet al., (2001) cattle ownership (especially ruminants) of each farmer family is generally limited to 3-5 lambs/goats or 1-2 cows/buffalos. This is related to the limited land and capital. Paat (2009) explains that at village scale, the development of farming in North Sulawesi Utara tends to be left behind compared with agriculture. Government funding priority with various subsidies and incentives are generally directed to food crops commodities. This created imbalance between the progresses of agriculture subsectors. Due to the inequality developed animal husbandry tends to be done by developed/independent groups, i.e. strong economic groups around cities.

Most cattle businesses in North Sulawesi haven't been managed commercially. According to Wantasen et al., (2013) cow businesses in Minahasaare mostly traditional businesses with small scale and use simple technology. The main characteristic of family animal husbandry is managed by the household and family members. Generally, their purposes are to process land and transport plants. The phenomenon is household behaviors as producers in economic activity. The household doesn't only act as producer and labor distributor, but also consumer. Family members are allocated for cattle business and other farming activities such as food crops to create household income.

The success of cattle business depends on three elements, which are seed, feed and management. According to Talib and Talib (2008), the basic principles of developing and increasing cow production are availability of good cow seeds, adequate fodder for optimal growth, opportunity to apply selection on cattle effectively, supporting institution as well as market to accept the products produced at profitable price. Selling price is very important in developing a cow nursery because it requires a long time period as well as a large amount of money. Management includes mating management, feeding, caging and livestock health. Management also includes handling livestock products, marketing, and organizing labors (Eli et al., 2008). According to Santosa (2003) in traditional cattle rearing, most resources are obtained without monetary transaction (no purchase, for example, in obtaining green fodder). Farmers with limited resources perform 
various plant and cattle production activities and activities outside of their agricultural businesses. All activities are interrelated and support each other so that they can increase overall productivity of the farm. Cattle business management depends on the availability of fodder sources, physical and biophysical conditions of the environment. Siswati and Ariyanto (2012) explains further that the development of a farmer's business is related to the his/her decisions which are heavily influenced by internal and external factors, i.e. availability of input, land, capital, labors, seasons, skills, market with proper price, transport, financial institutions and other institutions. Business decisions are also influenced by household decisions, i.e. consumption and human resources investment.

Livestock development is inhibited by land and fodder availability. Increase of land use for housing and industry reduces land availability for livestock herding. Fodder quality indry season is also one of the problems in livestock farming. During dry season the fodder usually used is rice straws, while the quality of rice straws fodders is usually low and the amount is often not enough. Therefore, there should be efforts to increase quality fodder availability during rainy and dry seasons (Saisoong, 1987). Sitompul et al., (2005) explains that the success of large ruminants performance improvement requires stable condition, meaning adequate management, continuous fodder availability throughout the year and environmental health. Feeding pattern which doesn't match livestock's needs is the main factor of low livestock productivity in tropical regions. However, to reach the expected result, i.e. high production level, improvement of cow genetic quality, especially local beef cattle must be balanced by fodders improvement and feeding patterns which meet livestock's needs.

One of the causes of low cow population is the availability of feeder cattle. According to Diwyanto and Priyanti (2005), now 99\% cattle businesses to produce fodder cattle (cow-calf operation) are by smallholders farms so that most of them are small scale. The business is usually integrated with other businesses so that the role of livestock (cows) is very complex in supporting the life of farmer families. There is nearly no investor interested to develop cow-calf operation, even existing produceror breederare almost unable to survive. Cowcalf operation to produce calves of feeder cattle requires high feed cost. Assuming average calving interval is around 500 days and feed cost of a mother is Rp. 4.000,-/day, then the feed cost to produce a calf is at least $\mathrm{Rp} 2$ million. This makes no investor willing to invest capital for cow-calf operation.

\section{Reseearch Settings}

The study was conducted in Tenga, Sinonsayang and West Amurang Sub-Districts, South Minahasa Regency on November 2011 to February 2012. South Minahasa Regency was chosen as research area because South Minahasa Regency is one of the centers of beef cattle and coconut production is North Sulawesi.

\section{Sampling Techniques and Data Collection}

Primary data include farmers' characteristics, area size, labors, capital, number of livestock, corn and rice seeds, inorganic fertilizers, pesticide, herbicide, coconut, corn, rice productions, fodders, veterinary drugs and livestock admission. Secondary data include cattle population data, coconut production, climate data, sizes of agricultural lands, population condition, etc. in North Sulawesi by Regency/city, Sub-districts in South Minahasa Regency.

\section{Data Analysis}

Data analysis tool used was Analysis of Variance (ANOVA) and linear regression analysis. ANOVA was used to compare income and cost of agricultural business on various types of business. Regression analysis was used to test factors influencing the income of integrated farming system.

\section{Results and Discussion}

\section{Description of Research Location}

Environmental and climate conditions in South Minahasa support agricultural development in South Minahasa. Agricultural sector in South Minahasa regency includes food crops, vegetables, ornamental plants, fruits, and plantations.

Table 1. Acreage, Harvested Area, Production and Productivity of Several Agricultural Commodities in South Minahasa Regency in 2011

\begin{tabular}{llrrrr}
\hline No & Commodities & Acreage (Ha) & $\begin{array}{r}\text { Harvested Area } \\
\text { (Ha) }\end{array}$ & Production (ton) & $\begin{array}{c}\text { Productivity } \\
\text { (ton/ha) }\end{array}$ \\
\hline 1 & Rice & 13.031 & 13.018 & 72.080 & 5,54 \\
\hline 2 & Upland Rice & 2.227 & 1.574 & 4.205 & 2,67 \\
\hline 3 & Corn & 20.888 & 20.882 & 82.330 & 3,94 \\
\hline 4 & Cassavas & 273 & 285 & 3.791 & 1.917 \\
\hline 5 & Sweet Potatoes & 200 & 197 & 1.096 & 1,73 \\
\hline 6 & Peanuts & 432 & 773 & 49.375 & \\
\hline 7 & Coconut & 45.041 & 45.041 & & 1,33 \\
\hline
\end{tabular}


Integrated Farming System Model in South Minahasa Regency - North Sulawesi

\begin{tabular}{rlrccc}
\hline 8 & Clove & 19.585 & 19.585 & 13.215 & 0,67 \\
\hline 9 & Others & 20.561 & & & \\
\hline & & 102.805 & 81.560 & 152.752 & \\
\hline
\end{tabular}

Sources: SouthMinahasain Figures2011, (http://minselkab.bps.go.id/publikasi/ddaminsel2011/index.html)

Generally food commodities produced by the community are rice (rice and upland rice), corns, cassavas, sweet potatoes, peanuts, and soy beans. Vegetables productivity in 2011 in South Minahasa Regency didn't experience significant change compared with 2010. Fruits productions in South Minahasa Regency consist of rambutan, rose apples, pineapples, oranges, duku, avocadoes, papaya, mangoes, mangosteens, jackfruits, and bananas. Biggest fruit productions in South Minahasa Regency are bananas and rambutan.

Plantation plants productions in South Minahasa Regency consist of coconuts, cloves, nutmegs, cocoa, coffee, and sugar palms. Biggest plantation plant production in South Minahasa Regency is coconut, reaching 49.375,12 tons.

Table 1 shows that in South Minahasa Regency, highest acreage is coconut which is 45.041 acres, with 49.375 tons production value. Corn is the food crop with the highest harvested area among other food crops, which is 20.882 with 3,94 tons per acre production. Rice has 13.031 acres of acreage, with 13.018 acres of harvested area, and 72.080 tons production, so average production is 5,54 tons/acre. The sizes of coconut, rice and corn fields haven't been used to develop livestock sector. This is because coconut plantations can become herding areas and can provide greeneries such as grass and cover crops. Greeneries available around coconuts plantations can be used fodders to reduce feed cost. The size of rice and corn area provide fodder potentials from corn and rice wastes. The abundance of fodders from coconuts plantations, corn and rice fields make South Minahasa Regency has potentials for greater livestock development.

Table 2. Livestock population in South Minahasa regency in 2011

\begin{tabular}{llrccc}
\hline No & \multicolumn{1}{c}{ Sub-district } & Cow & Horse & Goat & Pig \\
\hline 1. & Amurang & 184 & 30 & 207 & 1.267 \\
\hline 2. & Amurang Barat & 1,710 & 15 & 228 & 1.867 \\
\hline 3. & Amurang Timur & 435 & 10 & - & 1.050 \\
\hline 4. & Tareran & 410 & 10 & - & 1.980 \\
\hline 5. & Tenonga & 2,585 & - & 296 & 2.500 \\
\hline 6. & Sinonsayang & 2,170 & - & 594 & 2.180 \\
\hline 7. & Tumpaan & 452 & 35 & 257 & 1.621 \\
\hline 8. & Tatapaan & 1,308 & - & 265 & 978 \\
\hline 9. & Motoling & 450 & - & - & 964 \\
\hline 10. & Kumelembuai & 794 & - & - & 2.145 \\
\hline 11. & Ranoyapo & 803 & 13 & - & 2.474 \\
\hline 12. & Tompasbaru & 770 & 15 & 286 & 973 \\
\hline 13. & Maesaan & 1,400 & 15 & 262 & 980 \\
\hline 14. & Modoinding & 160 & - & - & 646 \\
\hline 15. & Motoling Timur & 835 & - & - & 1.343 \\
\hline 16. & Motoling Barat & 860 & - & - & 986 \\
\hline 17. & Suluun Tareran & 620 & - & - & 2.124 \\
\hline & Total & 15,946 & 143 & 2.395 & 25.978 \\
\hline
\end{tabular}

Sources: SouthMinahasain Figures2011 (http://minselkab.bps.go.id/publikasi/ddaminsel2011/index.html)

Cows are important livestock in South Minahasa Regency. Cattle population is in second place after pigs. Comparison of populations of several livestock in South Minahasa Regency is shown in Figure 5. In South Minahasa regency the purpose of keeping cows is not only to produce meat, but also for transport and to process agricultural lands. In 2011, cattle produce can provide $358.506 \mathrm{~kg}$ of consumable meat.

In agriculture and plantation, cows have a very important role. Uneven and hilly land made transportation to and from plantations difficult, so cows are used to draw carts to and from plantations. Ox carts are used to transport agricultural tools such as fertilizers to plantations, and harvest from plantation to houses. Ox carts are cheap and economical transports, hence cattle population is spread evenly in all sub-districts in South Minahasa Regency (Table 2). In agriculture, cows can be used to process land. Cows also produce manures which can be used as organic fertilizer for agricultural and plantation crops. Using manures as organic fertilizer can reduce the cost of buying fertilizers and maintain soil fertility. Application of organic fertilizer on soil can increase plants production so that farmers' income increase.

\section{Integration Model: Coconut Farms Income}

The first section will review coconut farms income. Based on analysis of variance it was discovered that farming system has significant influence on farmers' income. Every farming system produces different total coconut income. 
Table 3. Average total coconut farms income

\begin{tabular}{|l|c|c|}
\hline Farmings system & land area(hectares) & Income (Rp) \\
\hline Non integrated coconuts & 1.03 & $4,358,050.0 \mathrm{~b}$ \\
\hline Cows-coconuts & 1.51 & $7,995,196.7 \mathrm{a}$ \\
\hline Cows-coconuts-corns & 1.55 & $10,002,750.0 \mathrm{a}$ \\
\hline Cows-coconuts-rice & 1.53 & $9,371,845.0 \mathrm{a}$ \\
\hline Cows-coconuts-corns-rice & 1.54 & $10,327,503.0 \mathrm{a}$ \\
\hline
\end{tabular}

Note: Figuresin the same columnindicatesnosignificant differenceinHST 5\%

Table 4. Linear regression model of integrated coconuts-cows and non-integrated farming

\begin{tabular}{|c|c|}
\hline \multicolumn{2}{|r|}{ systems } \\
\hline Farmings system & Regression Models \\
\hline Non integrated coconuts & $\begin{array}{l}\text { Totalcoconutsrevenues }(\mathrm{Rp})=4,358,050+516,939.7 \text { land areas (hectares) }+ \\
575,390 \text { herbicides }(\mathrm{Rp})+600,871.4 \text { inorganicfertilizers }(\mathrm{Rp})+234,987.3 \\
\text { pesticides }(\mathrm{Rp})+468,517 \text { hired labors cost }(\mathrm{Rp})\end{array}$ \\
\hline Coconuts - cows & $\begin{array}{l}\text { Totalcoconutsrevenues }(\mathrm{Rp})=7,995,197+911,453.6 \text { land areas (hectares) }+ \\
1,378,932 \text { herbicides }(\mathrm{Rp})+1,219,705 \text { inorganicfertilizers }(\mathrm{Rp})+771,725.2 \\
\text { pesticides }(\mathrm{Rp})+743,374,8 \text { hired labors cost }(\mathrm{Rp})\end{array}$ \\
\hline Coconuts - cows - corns & $\begin{array}{l}\text { Totalcoconutsrevenues }(\mathrm{Rp})=10,002,750+1,076,569 \text { land areas (hectares) }+ \\
200,039.6 \text { herbicides }(\mathrm{Rp})+949,404.6 \text { inorganicfertilizers }(\mathrm{Rp})+553,965 \\
\text { pesticides }(\mathrm{Rp})+886,239.5 \text { hired labors cost }(\mathrm{Rp})\end{array}$ \\
\hline Coconuts - cows - rice & $\begin{array}{l}\text { Totalcoconutsrevenues }(\mathrm{Rp})=9,371,845+1,576,919 \text { land areas (hectares)+ } \\
469,487 \text { herbicides }(\mathrm{Rp})+569,859.3 \text { inorganicfertilizers }(\mathrm{Rp})+402,915.7 \\
\text { pesticides }(\mathrm{Rp})+1,588,133 \text { hired labors cost }(\mathrm{Rp})\end{array}$ \\
\hline Coconuts - cows - corns - rice & $\begin{array}{l}\text { Totalcoconutsrevenues }(\mathrm{Rp})=10,327,503+891,000.7 \text { land areas (hectares)+ } \\
896,924.8 \text { herbicides }(\mathrm{Rp})+841,330 \text { inorganicfertilizers }(\mathrm{Rp})+688,592.1 \\
\text { pesticides }(\mathrm{Rp})+893,918 \text { hired labors cost }(\mathrm{Rp})\end{array}$ \\
\hline
\end{tabular}

Table 3 shows that coconut farmers with non-integrated system has lower income from coconut farms compared with integrated system. Integrated farming system between cows and plants can increase farmers' income.

Various integrated system used by coconut farmers (cows-coconuts, cows-coconuts-corns, cows-coconuts-rice and cows-coconuts-corns-rice) produce similar total income of coconuts farms.

Based on linear regression model (Table 4) it was discovered that land size, cost of herbicides, inorganic fertilizers, pesticides, and hired labors have positive influences on farmers' income from integrated and non integrated coconut farming systems of cattle businesses (Table 4). It shows that every increase of components influencing coconut farms income will influence the increase of coconut farmers' income.

In non-integrated coconut system and coconut-cow integrated system, the biggest contributions to farmers' income are increasing fertilizers cost, herbicides cost, and land size. The higher the fertilizers cost, herbicides cost, and land size, the higher the farmers' income. In coconuts-cows-corns and coconut-cows-rice integrated farming systems, the biggest contributions to the increase of farmers' income are adding land size, fertilizers, hired labors cost, while the contributions of increasing pesticides and herbicides costs on coconuts farmers' income are lower. Regression model (Table 4) in coconuts-cows-corns-rice integrated system shows the increase of coconut farms areas, pesticides cost, hired labors cost, and herbicides cost have equal contributions to the increase of coconut farmers' income which is $\mathrm{Rp} \mathrm{891,007-Rp} \mathrm{896,924.} \mathrm{Increasing}$ pesticides cost have lower contribution compared with other factors of coconut farms in increasing income.

\section{Integration Model: Cattle Business Income}

Based on analysis of variance it was discovered that farming system doesn't have significant influence on farmers' net income. It shows that farmers' net income from cows isn't influenced by choice of farming system. In Table 5, it was discovered that average farmers' net income from cattle in every system doesn't have significant difference between various farming systems. Farmers' net income is obtained from total income from cattle business minus total cost of cattle rearing.

Table 5. Average income of cattle business farmers with integrated and non-integrated farming systems

\begin{tabular}{lc}
\hline \multicolumn{1}{c}{ Farmings system } & Income $(\mathrm{Rp})$ \\
\hline Non integrated coconuts & $11,550,525$ \\
\hline Coconuts - cows & $10,413,825$ \\
\hline Coconuts - cows - corns & $12,134,133$ \\
\hline Coconuts- cows - rice & $12,056,892$ \\
\hline Coconuts - cows - corns - rice & $11,824,542$ \\
\hline HST 5\% & tn \\
\hline \multicolumn{2}{c}{ Note $:$ th = no significant difference }
\end{tabular}


Table 6. Regression model cattle income on various cattle business systems

\begin{tabular}{ll}
\hline \multicolumn{1}{c}{ Farmings system } & \multicolumn{1}{c}{ Regression equations } \\
\hline Non integrated coconuts & Totalrevenuescow $(\mathrm{Rp})=11,561,058+1,138,076$ number ofcowskept $(\mathrm{UT})+$ \\
& 982,110 totalfeed costs $(\mathrm{Rp})+521,146.1$ totallivestockdrugs $(\mathrm{Rp})$ \\
\hline Coconuts - cows & Totalrevenuescow $(\mathrm{Rp})=10,413,825+1,803,530$ number ofcowskept (UT) + \\
& $1,524,166$ totalfeed costs $(\mathrm{Rp})+649,229.8$ totallivestockdrugs $(\mathrm{Rp})$ \\
\hline Coconuts - cows - corns & Totalrevenuescow $(\mathrm{Rp})=12,134,133+1,494,574$ number ofcowskept $(\mathrm{UT})+$ \\
\hline Coconuts - cows - rice & 509,574 totalfeed costs $(\mathrm{Rp})+458,277$ totallivestockdrugs $(\mathrm{Rp})$ \\
\hline Coconuts - cows - corns - rice & Totalrevenuescow $(\mathrm{Rp})=12,056,892+2,191,919$ number ofcowskept (UT) + \\
& $1,838,153$ totalfeed costs $(\mathrm{Rp})+892,438.8$ totallivestockdrugs $(\mathrm{Rp})$ \\
\hline & Totalrevenuescow $(\mathrm{Rp})=11,824,542+1,336,940.3$ number ofcowskept (UT) + \\
\hline
\end{tabular}

Based on analysis of variance (Table 5) it was discovered that various integrated and no-integrated farming systems don't have significant influence on teh results of cattle sales and total cattle income. Various integrated and non-integrated farming systems have significant influence on the income of cattle rental services.

Based on linear regression analysis it was discovered that the factor of number of cows kept, total feed cost and total veterinary drugs cost have positive influences on the increase of farmers' income (Table 6). It shows that the higher the cost expended by farmers on every component above, the higher the increase of the farmers' income.

Based on regression analysis (Table 6)it was discovered that the number of cows kept, total feed cost and veterinary drugs have positive influences on farmers' income by rearing cattle. It shows that every increase of number of cattle or fed and veterinary drugs cost will increase farmers' income in cattle rearing. Increase of number of cattle kept have the biggest contribution in increase of farmers; income in rearing cattle. The higher the number of cattle, the higher the farmers' income. The lowest contribution to the increase of farmers' income is te increase of total veterinary drugs which is $\mathrm{Rp} 458.277$ to $\mathrm{Rp} 892.438,8$.

\section{Integration Model: Corn Farming Income}

Based on analysis of variance it was discovered that farming system doesn't have significant influence on total farmers' income from corn farming. Table 7 shows that total farmers' income by planting corn between coconut trees in coconuts-cows-corns-rice system doesn't have significant difference from corn farming with coconuts-cows-corns system in growing seasons 1 and 2. Both systems produce $\operatorname{Rp~7.141.884,0~-~Rp~7.472.600~}$ from corn farming per season.

\begin{tabular}{ccc}
\multicolumn{3}{c}{ Table 7. Average corn farming income } \\
\hline System & land area(hectares) & Income (Rp) \\
\hline Coconuts-cows-corns & & \\
\hline Growing season 1 & 1.55 & $7,141,884.0$ \\
\hline Growing season 2 & 1.55 & $7,257,822.5$ \\
\hline Coconuts-cows-corns-rice & 1.54 & $7,472,600.0$ \\
\hline
\end{tabular}

Table 8. Regression Model of Corn

\begin{tabular}{|c|c|}
\hline System & Regression models \\
\hline Cococnuts-cows-corns & $\begin{array}{l}\text { income }=7,257,823+362,809 \text { land area(hectares) }+355,263 \text { seeds }(\mathrm{Rp}) \\
+338,751.9 \text { urea }(\mathrm{Rp}) \quad+351,385.4 \mathrm{SP}-36 \quad(\mathrm{Rp}) \\
+350,384.8 \mathrm{KCl}\end{array}$ \\
\hline Coconuts-cows-corns-rice & $\begin{array}{l}\text { income }=7,472,601+439,210.8 \text { land area(hectares) } \\
+419,531.5 \text { urea }(\mathrm{Rp}) \quad+432,708.1 \mathrm{SP}-36 \quad(\mathrm{Rp}) \\
+435,510.4 \mathrm{KCl}\end{array}$ \\
\hline
\end{tabular}

Table 8 shows that land size, number of seeds, inorganic fertilizer, pesticide and labor cost have positive influence on the increase of farmers' income from corn farming between coconut trees. Every increase of the factors above will influence the increase of farmers' income. The sizes of the seven factors' contributions to the increase of farmers' income are not significantly different.

Integration Model: Rice Farming Income

Table 9. Rice income in various integrated farming systems and growing seasons

\begin{tabular}{ccc}
\hline System & land area(hectares) & Income (Rp) \\
\hline Coconuts-cows-rice & & \\
\hline Growing season 1 & 1.55 & $5,099,761.7$ \\
\hline Growing season 2 & 1.55 & $4,972,745.8$ \\
\hline Coconuts-cows-corns-rice & 1.54 & $5,640,075.8$ \\
\hline Growing season 1 & 1.54 & $5,592,293.3$ \\
\hline Growing season 2 & & tn \\
\hline
\end{tabular}


Based on analysis of variance (Table 9) it discovered that integrated farming system doesn't have significant influence on the increase of farmers' income. Table 9 shows that average rice income in cowscoconuts-rice system in growing seasons 1 and 2 is not significantly different from farmers' income in coconutscows-rice-corns in growing seasons 1 and 2.

\section{Conclusions and Suggestions}

Integrated farming system which involves food crops in coconuts and cows systems produced higher income than coconuts-cows system, or non-integrated coconut and cows. The recommendation from the study is to optimize coconut farms with food crops and livestock to increase farmers' income. Thus, there should be further study to improve techniques of cultivating food crops between coconut trees, so that coconut and food crops production will increase.

\section{References}

[1] Diwyanto, K., R. Bambang dan D. Lubis. 2001. Integrasi Tanaman-Ternak dalamPengembangan Agribisnis yang berdaya Saing, Berkelanjutan dan Berkerakyatan (in Indonesian). National Seminar on Livestock on Veteriner 2001. p. 17-26.

[2] Diwyanto, K dan E. Handiwirawan. 2005. Peran Litbang dalam Mendukung Usaha Agribisnis Pola Integrasi Tanaman-Ternak (in Indonesian). National Seminar Integrated Farming System. p. 63-80.

[3] Diwyanto, K dan A. Priyanti. 2005. Prospek Pengembangan ternak Pola Integrasi Berbasis Sumberdaya Lokal (in Indonesian). Workshop onDevelopment ofPalm Coconut Systems Integration-Cow. p. 10-19.

[4] Elly, F.H., B.M. Sinaga., S.U. Kuntjoro dan N. Kusnadi. 2008. Pengembangan Usaha Ternak Sapi Rakyat Melalui Integrasi SapiTanaman di Sulawesi Utara (in Indonesian). Journal ofAgricultural Research. 27 (2) : 63-68.

[5] Haryanto, B. 2009. Inovasi Teknologi Pakan Ternak dalam Sistem Integrasi Tanaman -Ternak Bebas Limbah mendukung Upaya Peningkatan produksi Daging (in Indonesian). Development ofAgricultural Innovation. 2 (3) : 163-176.

[6] Ifar, S. 2007. Peran Ruminansia dalam Sistem Pertanian (Referensi untuk Integrasi Sapi pada Crash Program Agribisnis Jagung di Sulawesi Utara) (in Indonesian). J. Tropicallivestock. 6 (2) : 71-78.

[7] Moog, F.A. 2006. Country Pasture/Forage Resource Profiles. FAO. p. 5-23.

[8] Paat, P.C. 2009a. Sistem Integrasi Tanaman dan Ternak pada Lahan Kering Berbasis Kelapa di Sulawesi Utara. Seminar Regional Inovasi Teknologi Pertanian, Mendukung Program Pembangunan Pertanian Sulawesi Utara (in Indonesian). p. 404-412.

[9] Paat, P.C. 2009b. Analisis Potensi Sumberdaya Pakan dan Kebutuhan Inovasi Ternak Ruminansia di Kabupaten Minahasa Tenggara Sulawesi Utara (in Indonesian). RegionalSeminar onAgriculturalTechnologyInnovation. SupportsAgricultural DevelopmentProgramof NorthSulawesiProvince. p. 414- 425.

[10] Priyanto, D. 2011. Strategi Pengembangan Usaha Ternak Sapi Potong dalam Mendukung Program Swasembada Daging Sapi dan Kerbau Tahun 2014 (in Indonesian). Journal ofAgricultural Research. 30 (3) : $108-115$.

[11] Saisoong, C. 1987. Crops-Livestock Integration in Northeast Thailand : Problem and Prospects. Accessed on April 25 th 2013.

[12] Santosa, K.A. 2003. Pemberdayaan Peternak Sapi Potong Melalui Tridarma Perguruan Tinggi (in Indonesian). InaugurationSpeechTitleProfessor at theFaculty ofAnimal Husbandry Gadjahmada University.

[13] Siswati, L dan A. Ariyanto. 2012. Ekonomi Rumah Tangga Petani : Pola Pertanian Terpadu di Provinsi Riau (in Indonesian). Journal. Embrio. 5 (1) : 8-17.

[14] Sitompul, D.M., B.P. Manurung., I.W. Mathius dan Azmi. 2005. Integrasi Sapi-Sawit : Potensi Produk Samping dalam Pengembangan Ternak Sapi (in Indonesian). National Seminar Integrated Farming System. p. 468-473.

[15] Suryana. 2008. Peluang Pengembangan Model Integrasi Sapi dengan Perkebunan Kelapa Sawit Melalui Usaha Kemitaraan. Seminar Optimalisasi Hasil Samping Perkebunan Kelapa Sawit dan Industri Olahannya sebagai Pakan Ternak (in Indonesian). Seminar onOptimizingResultsSideOil Palm PlantationsandIndustriesManufacturedasLivestock Feed. p. 73-79.

[16] Talib, C dan R.A.B. Talib. 2008. Model Pembibitan Sapi Bali dalam Sistem Integrasi di Perkebunan Sawit (in Indonesian). National Seminar onTechnologyLivestockand Veteriner. p. 354-364.

[17] Wantasen, E., B. Hartono., N. Hanani and V. Panelewen. 2013. Income Upgrading Model of Cattleman in The Utilization of Artificial Insemination : A Case Study in Village of Kanonang III Regency of Minahasa-Indonesia. Sky Journal of Agricultural Research. 2 (2) : 20-27. 